\title{
Problem Posing Approach to Optimization Creative Thinking Ability on Mathematics for Elementary Students
}

\author{
Reza Syehma Bahtiar ${ }^{1, a^{*}}$, Diah Yovita Suryarini ${ }^{1, b}$ \\ ${ }^{1}$ Elementary Teacher Education Study Program, Faculty of Language and Science, Universitas Wijaya Kusuma Surabaya, Jawa Timur, 60225, Indonesia \\ asyehma@gmail.com; bdyovie24@gmail.com \\ ${ }^{*}$ Corresponding Author \\ Whatsapp Number: [+62 85745182452]
}

How to Cite : Bahtiar, R., S., Suryarini, D., Y. (2019). Problem Posing Approach to Optimization Creative Thinking Ability on Mathematics for Elementary Students. International Journal for Educational and Vocational Studies, 1 (5), 406-410

\section{ARTICLE HISTORY}

Received:7 June 2019

Revised: 14 August 2019

Accepted: 11 September 2019

\section{KEYWORDS}

Problem Posing Approach;

Creative Thinking;

Mathematics;

Elementary Students;

\section{ABSTRACT}

Mastery in creative thinking ability on Elementary school students have become a central issue in Indonesia education system. The ability to think creatively in learning Mathematics is needed in solving the problems, especially the problem in the form of stories. This study aimed to investigate the use of Problem Posing approach on creative thinking ability of elementary school students. The study is descriptive qualitative study. The students of fourth grade of elementary school were chosen as subject of the research. The data collected from the result of observation sheet and test and then analyzed using the scoring indicator rubrics, developed by Siswono. The result of this study showed that (1) By applying the problem posing approach, the activities of fourth grader elementary school students have increase in mathematics learning about the story problem on calculating mixed operations and (2) the application of the problem posing approach can improve the creative thinking ability of fourth grade students.

This is an open access article under the CC-BY-SA license.

\section{INTRODUCTION}

Education in Indonesia currently uses 2013 Curriculum (K-13) in teaching and learning process. Accordingly, the use of 2013 Curriculum requires teacher to be creative in carrying out teaching and learning activities in the classroom, so that students are able to understand and bring it into reality the teaching and learning process in its surroundings.

There is various subject in 2013 Curriculum that must be mastered by the students, one of them is Mathematics. Learning mathematics should begin with the introduction of problems that are appropriate to the situation (Contextual Problem). By proposing contextual problems, students are gradually guided to master mathematical concepts. In learning Mathematics, students are required to be more creative in learning the subject. Creativity in mathematics is more about the ability to think creatively since in general, most of the activities carried out by the one who studies mathematics are thinking (Saefudin, 2012).

Mastery in creative thinking ability on Elementary school students have become a central issue in Indonesia education system. The commitment about the importance of thinking skill has not fully come into realization in elementary school level, accordingly, the students are expected to be able to think creatively about the solving the problem with many alternative answers. This is in accordance with the statement (Suharman, 2005) which explain that the students are expected to think divergently, thinking processes that oriented in finding answers or many alternatives. This kind of thinking process can be done for solving mathematical problem, especially mathematical story problem. In this case, the teacher's role is to help the students in understanding the problem (Suharman, 2005).

The ability to think creatively in learning Mathematics is needed in solving the problems, especially the problem in the form of stories. In solving the problem, the students are expected to think creatively. To think creatively has the meaning that ones are able to have creativity or are able to think innovatively. All these terms are related to the efforts in finding, producing, and creating new things (Suharman, 2005). Krulik (as cited in Mariana, 2004), explained that reasoning is part of thinking in which the level is above recall. In reasoning, is categorized hierarchically/sequentially, namely basic thinking, critical thinking and creative thinking. The category is not 
discrete and it is very difficult to define it correctly. The following are the indicators that show each of these levels:

\section{a. Basic (basic)}

1). Understanding the concept

2). Recognize a concept when the concept is in a setting.

\section{b. Critical}

1) Test, connect and evaluate all aspects of a situation or problem

2) Focus on parts of a situation or problem

3) Collect and organize information

4) Validate and analyze information

5) Remember and associate the information learned before

6) Determine reasonable answers

7) Summarizing validly

8) Analytical and natural reflection

\section{c. Creative}

Original, effective and produce a complex product

1) Inventive

2) Synthesis of ideas

3) Building ideas

4) Applying ideas

This study regards how the students construct insight by building ideas based on their experience or their previously obtained material, combining ideas between material with their experiences and making improvements when implementing ideas that have been initiated. In creating, it is associated with three cognitive processes, namely generating, planning, and producing. Generating is a divergent phase that asks students to pay attention to the possibilities of solution of a task. If they get the possibility of solution, then a method is chosen in the form of an action plan. Finally, the plan is implemented by constructing a solution.

Siswono (as cited in Mariana, 2004) has developed a level of creative thinking (TBK) based on products of creativity (fluency, novelty, and flexibility) and creative thinking criteria from Krulik and Anderson. These levels are:

Level 5: Students at this level show an understanding of the assignment given. The results of student assignments fulfill all the criteria for product creativity in which the students are able to:

a) Build or generate mathematical ideas and material that have been learned as well as experienced from the surroundings environment.

b) Synthesize ideas from mathematical or other material that has been learned with experience the surrounding environment.

c) Implement ideas that were initiated as well as make improvements to get the answer to the task in accordance with the request.
Level 4: Students at this level show an understanding of the assignment given. The results of student assignments fulfill all the criteria for product creativity in which the students are able to:

a) Build or generate ideas from mathematical material that has been learned and little from the experience of the surrounding environment.

b) Synthesize (combine) ideas from mathematical or other material that has been learned with experience in the surrounding environment.

c) Implement ideas that were initiated as well as make improvements to get the answer to the task in accordance with the request.

Level 3: Students at this level show an understanding of the assignment given. The results of student assignments fulfill all the criteria for product creativity in which the students are able to:

a) Build or generate ideas only from mathematical material that has been learned.

b) Synthesize (combine) ideas from mathematical or other material that has been learned with experience in the surrounding environment.

c) Implement ideas that were initiated as well as make improvements to get the answer to the task in accordance with the request.

Level 2: Students at this level show an understanding of the assignment given. The results of student assignments fulfill all the criteria for product creativity in which the students are able to:

a) Build or generate ideas only from mathematical material that has been learned.

b) Synthesize (combine) ideas from mathematical or other material that has been learned with experience in the surrounding environment.

c) Not yet able to apply ideas that were initiated as well as make improvements to get the answer to the task in accordance with the request.

Level 1: Students at this level show an understanding of the assignment given. The results of student assignments fulfill all the criteria for product creativity in which the students are able to:

a) Build or generate ideas only from mathematical material that has been learned.

b) Not able to synthesize (combine) ideas from mathematical or other material that has been learned with experience in the surrounding environment.

c) Not yet able to apply ideas that were initiated as well as make improvements to get the answer to the task in accordance with the request.

Level 0: Students who are at this level, have not shown an understanding of the assignment given. The results of student assignments do not meet all the criteria for product creativity. Students do not show the process of creative thinking (just repeating or recalling) 
Table 1. Scoring Score on Creative Thinking Ability Indicators

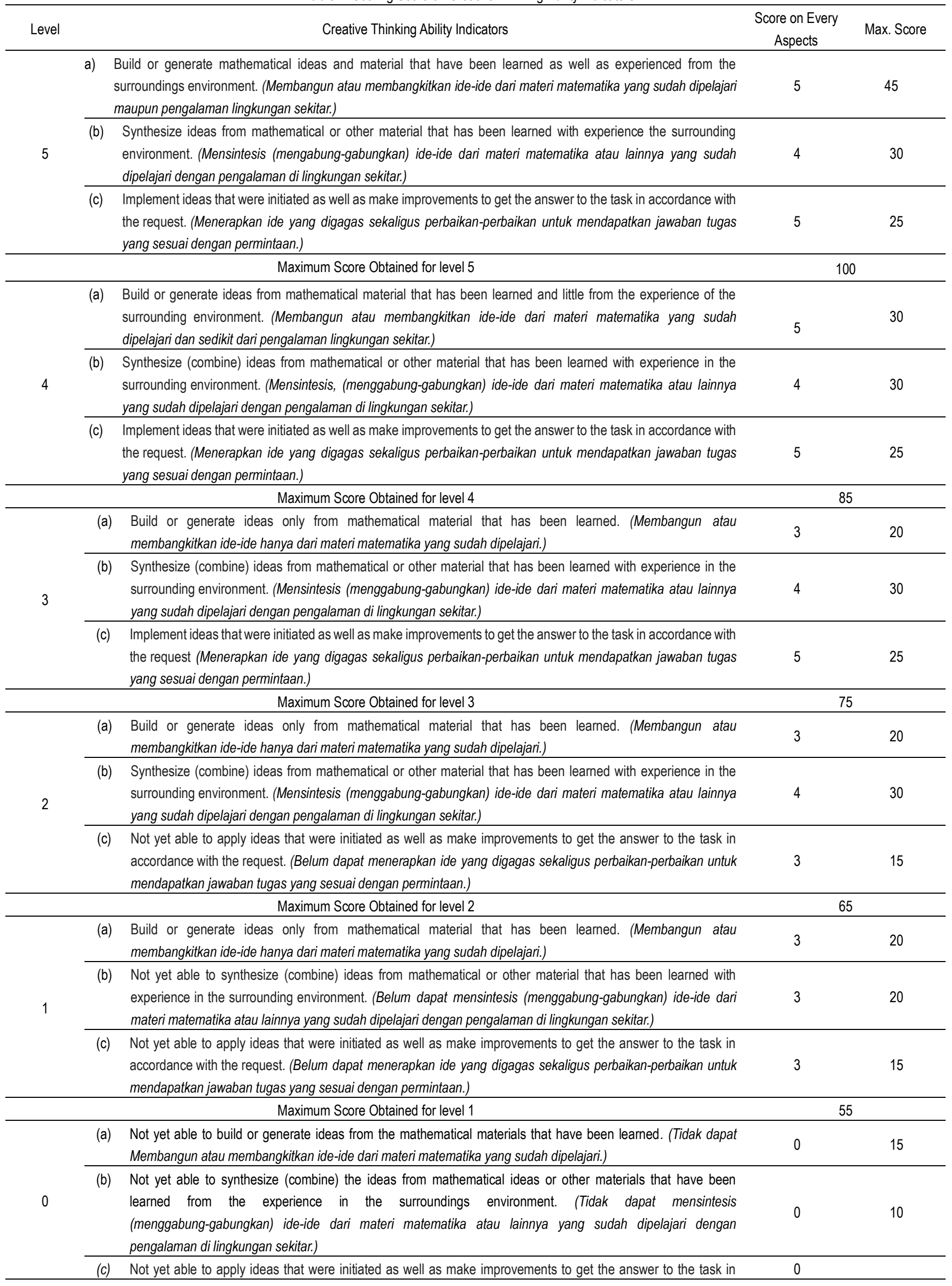


accordance with the request (Tidak dapat menerapkan ide yang digagas sekaligus perbaikan-perbaikan untuk

mendapatkan jawaban tugas yang sesuai dengan permintaan.)

Maximum Score Obtained for level 0

30

(Developed from Creative Thinking Ability Level by Siswono (as cited in Mariana, 2004)

Table 2. Creative Thinking Ability Level

\begin{tabular}{ccl}
\hline Score Range & Creative Thinking Category & Information \\
\hline $86-100$ & Level 5 & Very Creative (Sangat kreatif) \\
\hline $76-85$ & Level 4 & Creative (Kreatif) \\
\hline $66-75$ & Level 3 & Quite Creative (Cukup Kreatif) \\
\hline $56-65$ & Level 2 & Less Creative (Kurang Kreatif) \\
\hline $31-55$ & Level 1 & Very Less Creative (Sangat Kurang Kreatif) \\
\hline $0-30$ & Level 0 & Not Creative at all (Tidak Kreatof sama sekali) \\
\hline
\end{tabular}

(Developed from Creative Thinking Ability Level by Siswono (as cited in Mariana, 2004)

Considering the importance of creativity role in the education world, therefore it needs a method or approach that can encourage students' creative thinking ability in learning Mathematics. One of the approaches that can be used is a Problem Posing Approach. Mathematical Problem Posing provides an opportunity to interpret and analyze information critically, so students can distinguish significant data, find relationships between data, establish appropriate information to solve problems, and find coherent data. Problem posing provides students an experience to find and create their own mathematical problems. However, this kind of experience is lack own by the students (Putra, 2017). Furthermore (Mahmuzah, Ikhsan, \& Yusrizal, 2014) suggests that the problem posing approach is an activity with two different senses, which are (1) as the process of developing new mathematical problems/ questions by students based on existing situations and (2) as the process of reformulating Mathematical problems / questions with their own language based on the given situation. Accordingly, the essence of problem posing based on the expert opinion above is asking students to raise problems from a given condition. Background of the problems can be based on broad topics, similar questions that have been worked on or certain information given by the teacher to students. Problem Posing is a learning model that requires students to compose their own questions or break a question into simpler questions that refer to the resolution of the question. In learning, Problem Posing occupies a strategic position. Students must master the material and the sequence of problem solving in detail. This will be achieved if students enrich their knowledge not only from the teacher but also from their own learning independently.

\section{METHODS}

This study used qualitative methods with stages of research as follows: (1) collecting the literature of references; (2) collecting data and information; (3) collecting data on research objects; (4) Analyzing the problem; (5) Analyzing variables; (6) making research instruments in the form of observation sheets and interview question sheets; (7) analyzing data from the results of instruments that have been filled. The subjects in this study were fifth grade students of SD Siti Aminah Surabaya. The method used is Observation and Test. The data that has been collected in this study is then analyzed descriptively.

\section{RESULTS AND DISCUSSION}

In the results and discussion, the activities carried out by the researcher were described according to the procedure. Therefore, everything related to research is carried out properly, so as to produce research data that can be accounted for, in this section explain several things as follows:

\section{Student Activities}

Based on the results of student activities obtained from the results of observations, the calculation of the score data from the observation of student activities are: $3+3+$ $3+4+3+3+3+4+4+4+3+4+3+3+3+3+4+3+$ $4+3+3+3+3=76$. The average value for this aspect is $76 / 10=7.6$. This score is quite good because the maximum average or maximum score for each aspect is 4 or 92 for all aspects $(4 \times 23)$. This score can also be converted to standard 100. Conversion into standard 100 is $76 / 92 \times 100=82.6$. This shows that the learning model with the Problem Posing approach can be used in mathematics learning for the subject matter of mixed counting operations, where students are increasingly active in learning and follow the learning.

\section{Level of Student Thinking Ability}

Based on the results obtained from the initial tests carried out before the application of the Problem Posing approach and after applying the problem posing approach, the overall improvement of students' creative thinking skills has increased. This can be illustrated in diagram 1 the level of students' creative thinking abilities as follows: 


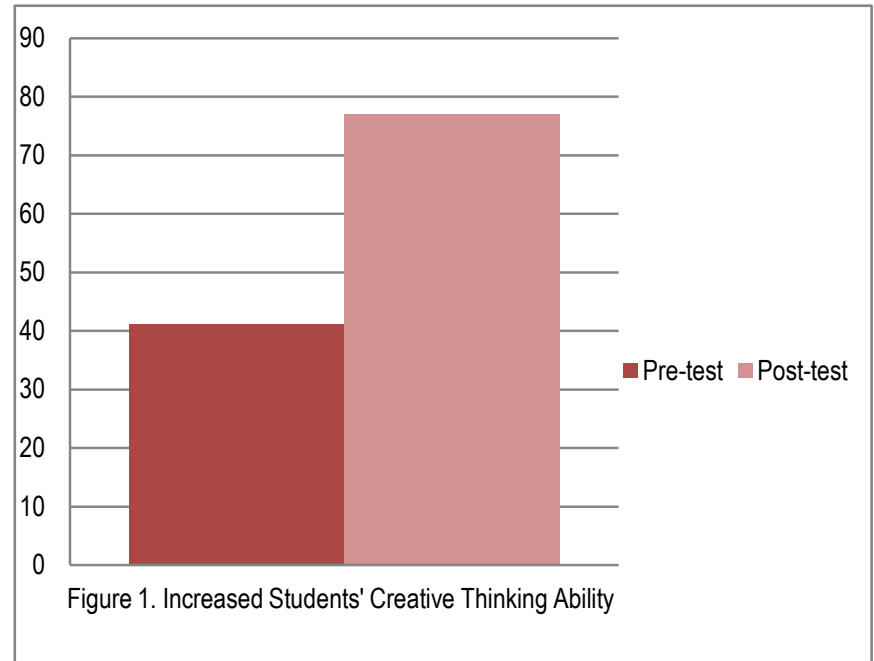

From diagram 1 above, it can be seen that at the beginning of the initial test, before the implementation, of the Problem Posing approach the average score obtained by students was 41.06 which was included in the category of very less creative ability level and after the application of the problem posing approach, the average student learning outcomes is 76.98 which is included in the category of creative thinking ability level. After the application of problem posing assessment, students gradually began to be able to ask some questions that were in accordance with the conditions given by the teacher. The students have been able ask questions, although there are still a limited number of questions, the language used in making questions and some problems that are difficult to solve. This is in line with the research (Amiluddin \& Sugiman, 2016) which states that the problem posing approach is able to improve student learning achievement on mathematics subjects.

\section{CONCLUSION}

Based on the results and discussion presented in the previous part, it can be concluded that (1) By applying the problem posing approach, the activities of Siti Aminah Surabaya elementary school students have increase in mathematics learning about the story problem on calculating mixed operations. This can be seen from the observation of student activities; (2) the application of the problem posing approach can improve the creative thinking ability of fourth grade students at SD Siti Aminah Surabaya, this is indicated by the average score obtained by all students through the test results of the application of the problem posing approach to creative thinking. of the Minister of Education and Culture of the Republic of Indonesia, Number 6. Chapter I Article 1. h. 3 .

Amiluddin, R., \& Sugiman, S. (2016). Pengaruh Problem Posing Dan PBL Terhadap Prestasi Belajar, Dan Motivasi Belajar Mahasiswa Pendidikan Matematika. Jurnal Riset Pendidikan Matematika, $3(1)$, 100-109. https://doi.org/10.21831/jrpm.v3i1.7303.

Mahmuzah, R., Ikhsan, M., \& Yusrizal. (2014). Peningkatan Kemampuan Berpikir Kritis dan Disposisi Matematis Siswa SMP dengan Menggunakan Pendekatan Problem Posing. Jurnal Didaktik Matematika, 1(2), 43-53.

Mariana, N. (2004). Identifikasi Proses Berpikir Kreatif Siswa Melalui Pengajuan Masalah (Problem Posing) Matematika Berpandu Dengan Model Creatif Problem Solving (CPS) Di Kelas IF SMP Negeri 4 Surabaya. Universitas Negeri Surabaya.

Putra, H. D. (2017). Pengembangan Instrumen Untuk Meningkatkan Kemampuan Mathematical Problem Posing Siswa SMA. Jurnal Euclid, 4(1), 636-645. Retrieved from http://jurnal.unswagati.ac.id/index.php/Euclid/articl e/view/211/211.

Saefudin, A. A. (2012). Pengembangan Kemampuan Berpikir Kreatif Siswa dalam Pembelajaran Matematika dengan Pendekatan Pendidikan Matematika Realistik Indonesia. Al-Bidayah, 4(1), 37-48. https://doi.org/10.22342/jme.1.1.791.11-16.

Suharnan. (2005). Psikologi Kognitif. Surabaya: Srikandi.

\section{REFERENCES}

RI Minister of Education Regulation 2018. (2018). About the Assignment of Teachers as Principals. Regulation 